\title{
Seroprevalence of varicella-zoster virus and predictors for seronegativity in the Amsterdam adult population
}

\author{
Gini GC van Rijckevorsel 1*, Marjolein Damen², Gerard J Sonder ${ }^{1,3}$, Maarten F Schim van der Loeff ${ }^{3,4}$
} and Anneke van den Hoek ${ }^{1,3}$

\begin{abstract}
Background: In the Netherlands, infection with varicella-zoster virus (VZV) is considered a benign common childhood illness and routine vaccination against VZV is not done. In 1995 it was estimated that $98-100 \%$ of the adult Dutch general population is immune, yet the estimate is based on a database in which a relative small number of people of non-Dutch ethnic origin were represented. As the city of Amsterdam has large immigrant communities originating from various subtropical and tropical countries, such as Morocco, Surinam, and Turkey with probably lower VZV transmission, this study aimed to estimate the seroprevalence of VZV IgG antibodies (antiVZV) among various ethnic groups in Amsterdam, and identify factors associated with seronegative VZV status.
\end{abstract}

Methods: The study was a cross-sectional survey of the Amsterdam population (2004), and the study sample was stratified by age and ethnicity, with deliberate oversampling of minority ethnic groups. Serum samples obtained from 1,341 residents in 2004 were tested for antibodies to VZV. Basic demographic data (gender, age, country of birth, age at immigration and number of children) were also available.

Results: The anti-VZV seroprevalence in the overall Amsterdam population was estimated to be $94 \%$ (95\% confidence intervals; 92-96\%). Regarding ethnic origin, first generation immigrants (Moroccan immigrants 90\%, Surinamese or Antillean immigrants 91\%, and Turkish 92\%), especially those that migrated after the age of 11 years, were more likely to be anti-VZV seronegative compared to those arriving at an earlier age or those born in the Netherlands (97-98\%). Both ethnic origin and generation of immigration were positive predictors for lgG seronegativity to VZV $(p<0.015)$. No other predictors for seronegativity were found.

Conclusion: The results of this study imply that about $4-8 \%$ of the general adult Amsterdam population is still susceptible to infection with VZV, and that susceptibility is even higher in some immigrant groups. When assessing the risk of infection after VZV exposure alertness is needed for vulnerable persons like pregnant women, patients with hematological malignancies or organ transplants in particular among first-generation immigrants.

\section{Background}

In the Netherlands, primary varicella infection (chicken pox) is considered a benign common childhood illness. After a first infection with varicella-zoster virus (VZV), immunity is regarded as life-long [1]. In later life, reactivation of latent VZV established in cells of the dorsal root ganglia after primary infection, may cause herpes zoster (shingles). Currently, routine vaccination against

\footnotetext{
* Correspondence: gvrijckevorsel@ggd.amsterdam.nl

${ }^{1}$ Public Health Service Amsterdam, Department of Infectious Diseases, Nieuwe Achtergracht 100, 1018 WT Amsterdam, the Netherlands Full list of author information is available at the end of the article
}

VZV is not done, although its introduction in the national immunization programme is now being evaluated [2].To assess the risk of infection after VZV exposure sound epidemiological data are needed to identify risk groups associated with VZV seronegativity.

VZV circulates widely in the Dutch population, and exposure to the virus is relatively frequent. The risk for VZV infection is highest in pre-school children aged 1-5 years, and by the age of 5 , at least $93 \%$ of the children have VZV antibodies. According to a national population-based VZV seroprevalence study (1995-1996), almost all Dutch adults (98-100\%) have antibodies against VZV, yet that study

\section{Ciomed Central}

(c) 2012 van Rijckevorsel et al.; licensee BioMed Central Ltd. This is an Open Access article distributed under the terms of the Creative Commons Attribution License (http://creativecommons.org/licenses/by/2.0), which permits unrestricted use, distribution, and reproduction in any medium, provided the original work is properly cited. 
included relatively few residents of non-Dutch origin [3-5]. This finding of near-total VZV seropositivity in the adult Dutch population, and the high risk of infection in young children is typical for a country in a region with a temperate climate. For unclear reasons the epidemiology of VZV shows great regional and seasonal variation. In subtropical and tropical climates the overall incidence of VZV infections is lower and infection occurs often at a later age; physical factors like different levels of ultra-violet radiation may play a role $[1,6,7]$. As the city of Amsterdam has large immigrant communities originating from various subtropical and tropical countries, such as Morocco, Surinam, and Turkey with probably lower VZV transmission, this study aimed to estimate the seroprevalence of VZV IgG antibodies (anti-VZV) among various ethnic groups in Amsterdam, and identify factors associated with seronegative VZV status.

\section{Methods}

\section{Study population and sampling procedure}

The data used for this study were obtained from a crosssectional population-based health survey (the Amsterdam Health Monitor, or AHM). The survey was carried out in 2004 by the Amsterdam Public Health Service (GGD) in collaboration with the National Institute for Public Health and the Environment (RIVM). Amsterdam consists of thirteen districts and the sample for the survey was drawn from five of them. These five contain a population that was representative concerning socioeconomic status and ethnicity for the total population of Amsterdam. The survey was approved by the Medical Ethics Committee of the Academic Medical Centre. The sample was stratified by ethnic background (Dutch, Moroccan, Turkish and other ethnic groups) and five age groups (18-34, 35-44, 45-54, 55-64, and 65 years or older). Within each stratum a random sample was drawn. The Turkish and Moroccan ethnic groups were oversampled to ensure sufficient numbers of individuals from these groups. Data were weighted to correct for oversampling by ethnic groups. After weighting the data for age, gender and ethnicity, respondents appeared to have an annual income and unemployment rate that was comparable to that of the total population of Amsterdam in 2004. The overall response rate among ethnic Dutch, Turkish and Moroccan subjects was $45 \%$. More details on the survey are described elsewhere $[8,9]$.

Respondents were invited for an interview and medical examination in a community health centre. All interviews were conducted in the language of choice of the respondent (i.e. Dutch, Turkish, Moroccan-Arabic or Berber). From all the issues that were addressed the following variables were considered pertinent to the current study: sex, age, country of birth of the participant and his/her parents, age at the time of migration, and the number and age of children living with the participant currently and/or in the past. Participants were classified into five ethnic groups (Dutch, Surinamese or Antillean, Turkish, Moroccan, and other), according to the self-reported country of birth and the country of birth of the respondent's mother or father. Furthermore, participants of non-Dutch ethnic origin were classified as first- or second-generation immigrants depending on their own country of birth. Those born in the Netherlands were considered as second-generation and all others as first-generation immigrants.

Participants were requested to provide a blood sample. These were collected, after obtaining written informed consent, and were stored at $7^{\circ} \mathrm{C}$ within 30 minutes, then centrifuged and frozen at $-80^{\circ} \mathrm{C}$ within $48 \mathrm{hr}$. Seventynine per cent of the participants $(n=1,376)$ donated a blood sample for the serum repository.

\section{Serological assays}

Plasma samples were tested for IgG-class antibodies to VZV by means of quantitative enzyme immunoassays. The assays were performed in the Public Health Laboratory in Amsterdam according to the instructions of the manufacturer. The serological test was a microplate enzyme-linked immunosorbent assay system that uses purified antigen (cell lysate of a human fibroblast cell line, VZV wild strain) to detect VZV IgG (EUROIMMUN Anti-Varicella-Zoster-Virus IgG-ELISA; Medizinische Labordiagnostika AG, Lübeck, Germany).

In estimating anti-VZV seroprevalence, only samples with a positive result were considered immune. All negative and equivocal test results (according to the manufacturer all results between 80 and $110 \mathrm{mIU} / \mathrm{ml}$ ) were considered as not immune. We thereby increased the specificity and reduced the number of false positive results. As the purpose of this study was to establish factors associated with VZV susceptibility, reduced assay sensitivity is preferable to reduced specificity [10].

\section{Statistical analysis}

In order to obtain results representative for the adult population in Amsterdam, prevalences and confidence intervals of $95 \%$ (95\%CI) corrected for stratification were calculated using the complex samples modules of SPSS, version 17 (SPSS Inc., Chicago, Illinois, USA). In these analyses data were weighted for age, sex and ethnic origin, using a weighing method which corrected the oversampling by ethnic groups as described elsewhere $[8,11,12]$. Prevalences $(\mathrm{P})$ and odds ratios $(\mathrm{OR})$ were estimated in the general Amsterdam population by taking into account the study design using Intercooled Stata 11.1 for Windows (Stata Corp., College Station, Texas, USA). Prevalences were compared using the Chi-square test; and a P-value of $<0.05$ was considered as significant. 


\section{Results}

\section{Characteristics of the study sample}

For this study, $97.5 \%(1,341 / 1,376)$ of the collected blood samples were available for laboratory analysis. Table 1 shows the characteristics of the 1,341 participants who were included. The table shows both the distribution in the study sample (non-weighted), and the estimated distribution representing the Amsterdam population. The study sample consisted of 619 men (46\%) and 717 women (54\%). Age ranged from 17 to 90 years. The median age for men was 52 years (interquartile range (IQR) 41-62 years) and for women 47 years (IQR 37-58 years). Most participants were of Dutch (33\%), Turkish (24\%), or Moroccan (21\%) ethnic origin. Within ethnic groups, there was an unequal distribution between the sexes for participants of Surinamese and Antillean ethnic origin (71\% was female), for participants of Dutch ethnic origin (59\% was female), and for participants of Moroccan ethnic origin (57\% was male). Of all 1,341 participants $61 \%$ (814) were born outside the Netherlands, of which the majority was first-generation Turkish (306) or Moroccan immigrant (262). Other first-generation immigrants came often from the Republic of Surinam and the Netherlands Antilles (78) or from Indonesia (32). The median age at immigration was 25 years (range $0-76$ years), and only a minority (64 or $8 \%$ ) of the immigrants came to live in the Netherlands before the age of 11 years. Only $4 \%$ (59) were second-generation immigrants. Half of the participants $(47 \%)$ had one or more children (median 2 children, range 1-10 children), and 29\% none. For 23\% of the group, data on having children were missing.

Seroprevalence of anti-VZV in the Amsterdam population Table 2 gives an overview of the test results and the estimated anti-VZV seroprevalence by demographic characteristics. The anti-VZV seroprevalence is shown both non-weighted, representing the study sample, and weighted, representing the Amsterdam population. The anti-VZV seroprevalence in the overall Amsterdam population was estimated to be $93.8 \%$ (95\% CI $91.6-$ 95.5\%). Regarding ethnic origin, seroprevalence was lowest among first-generation immigrants (Moroccan immigrants $90 \%$, Surinamese or Antillean immigrants 91\%, and Turkish 92\%) compared to those born in the Netherlands (Dutch ethnic origin and second-generation immigrants 97-98\%). Among the first-generation immigrants, those that migrated before the age of 11 were more likely to be seropositive, than those that migrated at a later age $(\mathrm{P}<0.001)$.

\section{Predictors for IgG seronegativity to VZV in the study sample}

The results of the univariable analysis for IgG seronegativity to VZV are shown in Table 3. All negative and equivocal test results were considered as IgG seronegative. Both ethnic origin and generation of immigration were positive predictors for IgG seronegativity to VZV. When considering the ethnic origin, people of Moroccan and Turkish ethnic origin were 2.5 times more likely to be seronegative compared to people from Dutch ethnic origin $(\mathrm{P}=0.013)$. Almost $10 \%$ of all first-generation immigrants from Morocco and Turkey were anti-VZV seronegative $(P=0.015)$. Immigrants that migrated after the age of 10 were more likely to be seronegative compared to those that migrated at a younger age and those born in the Netherlands $(\mathrm{P}=0.0001)$. No other predictors for seronegativity were found.

\section{Discussion}

Our study shows a high seroprevalence $(94 \%)$ of VZV IgG antibodies in the overall adult Amsterdam population (95\%CI 92-96\%), which is in line with other seroprevalence estimates in adults living in temperate zones [3,5,13-19]. A comparative sero-epidemiology study of anti-VZV in 11 countries in the European region found that seroprevalence was above $90 \%$ in all countries, except for Italy (88.8\%)[5] . The estimated seroprevalence in Amsterdam is rather low, compared to the near-total VZV seropositivity (97-100\%) in the adult Dutch population, but probably representative for a highly urbanized area. In a national population-based seroprevalence study in 1995, a significantly lower seroprevalence (93.6\%; 95\%CI 91.7-95.8\%) was found in highly urbanized municipalities, compared to rural regions (95.9\%; 95\%CI 95.2-96.6\%) [Personal communication; H. de Melker, Data from 'PIENTER 1995-1996']. Urbanization of $<2500$ addresses per square kilometer (sq.km) was an independent predictor for seropositivity of VZV compared to urbanization $\geq 2500$ addresses per sq. km (OR 2.1; 95\% CI 1.1-3.7) [3]. The difference was not easily explained [3,5,13,16,20,21].

One explanation for this difference may be the ethnic diversity present in urban populations. The city of Amsterdam has large migrant communities, with people originating from various subtropical and tropical countries, which are known to have less VZV transmission. In temperate regions, VZV causes annual epidemics among susceptible household members, in day care centers, and in schools, resulting in high seroprevalence. In warmer climates, VZV infection is less frequent and as many as $50 \%$ of young adults in tropical countries may never have had a primary VZV infection $[1,5,7,22]$. In this study, the relatively low anti-VZV seroprevalence in the Amsterdam adult population is explained by the presence of susceptible immigrants. First-generation immigrants did have a significantly lower seroprevalence than persons who were born in the Netherlands. On average, first-generation immigrants had a 2 times higher risk of 
Table 1 Characteristics of 1,341 participants of the Amsterdam Health Monitoring Survey, 2004

\begin{tabular}{|c|c|c|c|}
\hline \multirow{2}{*}{ Characteristics } & \multicolumn{2}{|c|}{ Study sample } & \multirow{2}{*}{$\frac{\text { Amsterdam adult population }}{\text { (Estimated proportion) }}$} \\
\hline & $\mathrm{n}$ & (\%) & \\
\hline Total & 1,341 & & \\
\hline \multicolumn{4}{|l|}{ Sex } \\
\hline Female & 717 & $(53.5)$ & 50.3 \\
\hline Male & 619 & $(46.2)$ & 49.7 \\
\hline Sex missing & 5 & $(0.4)$ & - \\
\hline \multicolumn{4}{|l|}{ Age category } \\
\hline $18-34$ & 212 & $(15.8)$ & 35.1 \\
\hline $35-44$ & 291 & $(21.7)$ & 23.8 \\
\hline $45-54$ & 325 & $(24.2)$ & 17.1 \\
\hline $55-64$ & 279 & $(20.8)$ & 12.0 \\
\hline 65 and older & 224 & $(16.7)$ & 12.0 \\
\hline Age missing & 10 & $(0.7)$ & - \\
\hline \multicolumn{4}{|l|}{ Ethnic origin } \\
\hline Dutch & 437 & $(32.6)$ & 53.5 \\
\hline Moroccan & 275 & $(20.5)$ & 6.9 \\
\hline 1st generation, Moroccan & 262 & - & - \\
\hline Surinamese or Antillean & 88 & (6.6) & 9.3 \\
\hline 1st generation, Surinamese or Antillean & 78 & - & - \\
\hline Turkish & 319 & $(23.8)$ & 4.4 \\
\hline 1st generation, Turkish & 306 & - & - \\
\hline Other ethnic origin & 212 & $(15.8)$ & 25.9 \\
\hline 1st generation, other ethnic origin & 189 & - & - \\
\hline Ethnic origin missing & 10 & $(0.7)$ & - \\
\hline \multicolumn{4}{|l|}{ Immigration status } \\
\hline Autochthonous (born in the Netherlands) & 516 & $(38.5)$ & 64.4 \\
\hline Immigrated at age $\leq 10$ years & 64 & $(4.8)$ & 5.8 \\
\hline Immigrated at age $>10$ years & 721 & $(53.8)$ & 29.8 \\
\hline Immigrated at unknown age & 32 & (2.4) & - \\
\hline Country of birth missing & 8 & (0.6) & - \\
\hline \multicolumn{4}{|l|}{ Having children } \\
\hline Yes & 634 & $(47.3)$ & 55.7 \\
\hline No & 394 & $(29.4)$ & 44.3 \\
\hline Missing & 313 & $(23.3)$ & - \\
\hline \multicolumn{4}{|l|}{ Number of children $(n=1,028)$} \\
\hline 0 & 394 & $(38.3)$ & 44.8 \\
\hline 1 & 203 & $(19.7)$ & 21.6 \\
\hline 2 & 239 & $(23.2)$ & 22.0 \\
\hline 3 or more & 176 & $(17.1)$ & 11.6 \\
\hline Number of children missing & 16 & $(1.2)$ & - \\
\hline
\end{tabular}

being anti-VZV seronegative. Furthermore there was a positive association between anti-VZV seroprevalence and the age of migration. In this study, the median age at immigration was 25 years, and most participating immigrants (665 or $84 \%$ ) migrated more than 11 years ago (data not shown). Immigrants who migrated after the age of 11 years were more likely to be seronegative compared to those that immigrated at a younger age. It 
Table 2 Prevalence of VZV IgG antibodies by demographic characteristics among 1,341 Amsterdam residents aged 18 years and older, 2004

\begin{tabular}{|c|c|c|c|c|c|c|}
\hline & \multicolumn{4}{|c|}{ Study sample } & \multicolumn{2}{|c|}{ The overall Amsterdam population } \\
\hline & $\mathbf{n}$ & $\%$ negative & $\%$ equivocal & $\%$ positive & $\%$ anti-VZV seropositive $(95 \% \mathrm{Cl})$ & P-value \\
\hline Total & 1,341 & 4.1 & 2.8 & 93.1 & $93.8(91.6-95.5)$ & \\
\hline Sex & & & & & & 0.29 \\
\hline Male & 619 & 4.2 & 2.9 & 92.9 & $92.8(89.0-95.4)$ & \\
\hline Female & 717 & 4.0 & 2.8 & 93.2 & $94.8(92.2-96.6)$ & \\
\hline Age category & & & & & & 0.42 \\
\hline 18-34 years & 212 & 4.7 & 2.4 & 92.9 & $92.0(86.3-95.5)$ & \\
\hline $35-44$ years & 291 & 4.1 & 3.4 & 92.4 & $95.0(90.8-97.3)$ & \\
\hline $45-54$ years & 325 & 4.9 & 3.1 & 92.0 & $93.5(89.3-96.1)$ & \\
\hline $55-64$ years & 279 & 2.2 & 2.5 & 95.3 & $96.4(92.4-98.4)$ & \\
\hline 65 years and older & 224 & 4.5 & 2.7 & 92.9 & $94.8(89.9-97.4)$ & \\
\hline Age missing & 10 & 10.0 & 0 & 90.0 & - & \\
\hline Ethnic origin & & & & & & 0.03 \\
\hline Dutch & 437 & 2.1 & 1.8 & 96.1 & $96.6(94.3-98.0)$ & \\
\hline Surinamese and Antillean & 89 & 5.6 & 1.1 & 93.3 & $93.0(80.2-97.8)$ & \\
\hline Turkish & 319 & 4.7 & 4.7 & 90.6 & $91.8(87.1-94.8)$ & \\
\hline Moroccan & 275 & 5.8 & 3.6 & 90.6 & $89.7(82.9-94.0)$ & \\
\hline Other & 211 & 4.7 & 1.9 & 93.6 & $90.0(82.8-94.3)$ & \\
\hline Ethnic origin missing & 10 & 0 & 0 & 100 & - & \\
\hline \multicolumn{7}{|l|}{ Generation } \\
\hline Dutch & 437 & 2.1 & 1.8 & 96.1 & $96.6(94.3-98.0)$ & 0.002 \\
\hline $1^{\text {st }}$ generation. Surinamese or Antillean & 78 & 6.4 & 1.3 & 92.3 & $90.6(74.7-96.9)$ & \\
\hline $1^{\text {st }}$ generation. Turkish & 306 & 4.6 & 4.9 & 90.5 & $91.5(86.5-94.7)$ & \\
\hline $1^{\text {st }}$ generation. Moroccan & 262 & 5.7 & 3.8 & 90.5 & $90.1(83.5-94.2)$ & \\
\hline Other $1^{\text {st }}$ generation & 189 & 5.3 & 2.1 & 92.6 & $87.9(79.7-93.0)$ & \\
\hline $2^{\text {nd }}$ generation immigrants & 59 & 3.4 & 0 & 96.6 & $98.3(91.3-99.7)$ & \\
\hline Ethnic origin missing & 10 & 0 & 0 & 100 & - & \\
\hline Immigration status & & & & & & 0.02 \\
\hline Autochthonous (born in the Netherlands) & 516 & 2.1 & 1.6 & 96.3 & - & \\
\hline Immigrated at age $>10$ years & 721 & 5.7 & 4.0 & 90.3 & $86.3(80.4-90.7)$ & \\
\hline Immigrated at age $\leq 10$ years & 64 & 1.6 & 1.6 & 96.9 & $97.5(87.8-99.5)$ & \\
\hline Immigrated at unknown age & 32 & 6.3 & 0 & 93.8 & - & \\
\hline Country of birth missing & 8 & 0 & 0 & 100 & - & \\
\hline Children & & & & & & 0.80 \\
\hline No & 394 & 4.1 & 2.8 & 93.2 & $93.3(88.7-96.1)$ & \\
\hline Yes & 634 & 4.3 & 3.3 & 92.4 & $94.7(91.1-96.9)$ & \\
\hline Data on having children missing & 313 & 3.8 & 1.9 & 94.3 & - & \\
\hline Number of children $(n=1,028)$ & & & & & & 0.94 \\
\hline 0 & 394 & 4.1 & 2.8 & 93.2 & $93.3(88.7-96.1)$ & \\
\hline 1 & 203 & 4.4 & 2.0 & 93.6 & $94.9(88.2-97.9)$ & \\
\hline 2 & 239 & 5.0 & 3.8 & 91.2 & $94.7(87.5-97.8)$ & \\
\hline 3 or more & 176 & 3.4 & 4.5 & 92.1 & $93.6(84.2-97.5)$ & \\
\hline Number of children missing & 16 & 0 & 0 & 100 & - & \\
\hline
\end{tabular}


Table 3 IgG seronegativity to VZV by demographic characteristics in the study sample aged 18 years and older, 2004

\begin{tabular}{|c|c|c|c|c|c|}
\hline & \multirow{2}{*}{$\mathbf{n}$} & \multicolumn{2}{|c|}{ VZV seronegative } & \multirow{2}{*}{$\begin{array}{c}\text { Univariable } \\
\text { OR (95\%) }\end{array}$} & \multirow[t]{2}{*}{ P-value } \\
\hline & & $\mathrm{n}$ & $\%$ & & \\
\hline Total & 1,341 & 93 & $6.9(5.6-8.4)$ & & \\
\hline Sex & & & & & 0.84 \\
\hline Male & 619 & 44 & 7.1 & 1 & \\
\hline Female & 717 & 49 & 6.8 & $0.96(0.6-1.5)$ & \\
\hline Age category & & & & & 0.52 \\
\hline 18-34 years & 212 & 15 & 7.1 & 1 & \\
\hline $35-44$ years & 291 & 22 & 7.6 & $1.07(0.5-2.1)$ & \\
\hline $45-54$ years & 325 & 26 & 8.0 & $1.14(0.6-2.2)$ & \\
\hline $55-64$ years & 279 & 13 & 4.7 & $0.64(0.3-1.4)$ & \\
\hline 65 years and older & 224 & 16 & 7.1 & $1.01(0.5-2.1)$ & \\
\hline Age missing & 10 & 1 & 10.0 & - & \\
\hline Ethnic origin & & & & & 0.013 \\
\hline Dutch & 437 & 17 & 3.9 & 1 & \\
\hline Surinamese or Antillean & 89 & 6 & 6.7 & $1.79(0.7-4.7)$ & \\
\hline Turkish & 319 & 30 & 9.4 & $2.56(1.4-4.7)$ & \\
\hline Moroccan & 275 & 26 & 9.5 & $2.58(1.4-4.8)$ & \\
\hline Other & 211 & 14 & 6.6 & $1.76(0.8-3.6)$ & \\
\hline Ethnic origin missing & 10 & 0 & 0 & - & \\
\hline \multicolumn{6}{|l|}{ Generation } \\
\hline Dutch & 437 & 17 & 3.9 & 1 & \\
\hline $1^{\text {st }}$ generation, Surinamese or Antillean & 78 & 6 & 7.7 & $2.06(0.8-5.4)$ & \\
\hline $1^{\text {st }}$ generation, Turkish & 306 & 29 & 9.5 & $2.59(1.4-4.8)$ & \\
\hline $1^{\text {st }}$ generation, Moroccan & 262 & 25 & 9.5 & $2.61(1.4-4.9)$ & \\
\hline Other $1^{\text {st }}$ generation & 189 & 14 & 7.4 & $1.98(1.0-4.1)$ & \\
\hline $2^{\text {nd }}$ generation immigrants & 59 & 2 & 3.4 & $0.87(0.2-3.9)$ & \\
\hline Ethnic origin missing & 10 & 0 & 0 & - & \\
\hline Immigration status & & & & & $<0.0001$ \\
\hline Autochthonous (born in the Netherlands) & 516 & 19 & 3.7 & $0.36(0.2-0.6)$ & \\
\hline Immigrated at age $>10$ years & 721 & 70 & 9.7 & 1 & \\
\hline Immigrated at age $\leq 10$ years & 64 & 2 & 3.1 & $0.3(0.1-1.3)$ & \\
\hline Immigrated at unknown age & 32 & 2 & 6.3 & - & \\
\hline Country of birth missing & 8 & 0 & 0 & - & \\
\hline Children & & & & & 0.57 \\
\hline No & 394 & 27 & 6.9 & 1 & \\
\hline Yes & 634 & 48 & 7.6 & $1.11(0.7-1.8)$ & \\
\hline Data on having children missing & 313 & 18 & 5.8 & $0.83(0.5-1.5)$ & \\
\hline Number of children $(n=1,028)$ & & & & & 0.75 \\
\hline 0 & 394 & 27 & 6.9 & 1 & \\
\hline 1 & 203 & 13 & 6.4 & $0.93(0.5-1.8)$ & \\
\hline 2 & 239 & 21 & 8.9 & $1.31(0.7-2.4)$ & \\
\hline 3 or more & 176 & 14 & 8.0 & $1.17(0.6-2.3)$ & \\
\hline Number of children missing & 16 & 0 & 0 & - & \\
\hline
\end{tabular}


is likely that new immigrants, especially the children, experience VZV infection after settling in the Netherlands, yet data on the incidence of VZV in immigrants in the Netherlands are lacking. A good number of Surinamese people who migrated to the Netherlands after the independence of Surinam in 1975, were referred to the outpatient department for sexually transmitted infections because of a vesicular rash, which was thought to be secondary syphilis but turned out to be chickenpox [Personal communication; A, van den Hoek]. Also, an outbreak of chickenpox among West-Indians residing in the Netherlands has been described [23]. Several surveys in other countries describe a low seroprevalence in immigrants and outbreaks of chickenpox among newly arrived migrants [24-27]. As in this study the only three variables eligible for inclusion into a multivariable model (ethnic origin; ethnic origin \& generation; immigration status) were nearly identical ('ethnic origin and ethnic origin \& generation') or collinear ('immigration status' and 'ethnic origin'), a multivariable analysis was not feasible.

Other studies have described that anti-VZV seroprevalence may be related to household composition ( $\geq 4$ persons) and school attendance by a household member $[3,6,28-30]$. However, in this study no association between anti-VZV seroprevalence and having children or the number of children was found.

In this study, we increased the specificity of the test by considering those with equivocal test results as nonimmune. This may have led to an underestimate of the true anti-VZV seroprevalence and thus the immunity in the Amsterdam population, and overestimated the VZV susceptibility. However, as the aim of this study was to identify factors associated with VZV susceptibility, and in order to reduce the number of false positives, this approach seems justified. A subsidiary analysis in which the equivocal test results were considered as false negative showed similar, although less significant outcomes (data not shown).

The relatively low response rate of the AHM (45\%) and its sampling methods may be considered as potential sources of bias, which may have affected the results of this study. However, the oversampling and nonresponse bias by ethnic groups were addressed by weighing the data by sex, age, and ethnicity. A non-responders survey showed that the sample appeared to be representative of the population on most health determinants [9]. Furthermore, a direct association between VZV infection and response to the AHM seems unlikely. For these reasons the weighted VZV prevalence may be considered representative for the whole adult population of Amsterdam.

The introduction of a two-dose universal childhood VZV vaccination programme in the Netherlands is being considered. In terms of health policies and the costeffectiveness of the introduction of a universal vaccination programme for VZV, the finding of $4-8 \%$ of adult susceptibles in Amsterdam should be taken into account. One of several unresolved questions is the impact of a VZV vaccination programme on the incidence of herpes zoster. Another issue related to cost-effectiveness is the uncertainty of the burden of disease of VZV in children [2]. Compared to neighboring countries, the Netherlands reports lower rates of complications of chickenpox in children [31]. With a universal childhood programme a shift in the age of primary VZV infection from childhood to adolescents and adults is likely to occur [5,32-35]. Primary VZV in adults and adolescents have, like pregnant women and immune-compromised individuals, an increased risk of complications $[1,29,36,37]$. As in the Netherlands chickenpox is not a notifiable disease, little is known on the incidence of primary VZV infection or its complications in adults, and the current overall burden of VZV infection in the adult population cannot be estimated. Improved surveillance is needed as a universal childhood vaccination programme will only change the risk of infection in VZV-negative adults long after its introduction.

\section{Conclusion}

In conclusion, the results of this study imply that about 4-8\% of the general adult Amsterdam population is still susceptible to infection with VZV, and that susceptibility is even higher in some immigrant groups. When assessing the risk of infection after VZV exposure alertness is needed for vulnerable persons like pregnant women, patients with hematological malignancies or organ transplants in particular among first-generation immigrants. [38].

\section{Competing interests}

The authors declare that they have no competing interests.

\section{Acknowledgements}

The authors would like to thank Joanne Ujcic-Voortman and Daan Uitenbroek for their comments on the statistical procedures; and Lucy Philips for editing the final manuscript. Furthermore the authors would like to thank Arjen Speksnijder, Martijn van Rooijen and all analysts of the Public Health Laboratory for their repeated dedication in testing, and re-testing the Amsterdam serum and plasma repository.

\section{Author details}

${ }^{1}$ Public Health Service Amsterdam, Department of Infectious Diseases, Nieuwe Achtergracht 100, 1018 WT Amsterdam, the Netherlands. ${ }^{2}$ Public Health Laboratory, Cluster of Infectious Diseases, Public Health Service of Amsterdam, Nieuwe Achtergracht 100, 1018 WT Amsterdam, the

Netherlands. ${ }^{3}$ Academic Medical Centre, Department of Internal Medicine, Division of Infectious Diseases, Tropical Medicine and AIDS, Meibergdreef 9, 1105 AZ Amsterdam, the Netherlands. ${ }^{4}$ Public Health Service Amsterdam, Cluster Infectious Diseases, Department of Research, Nieuwe Achtergracht 100, 1018 WT Amsterdam, the Netherlands. 


\section{Authors' contributions}

GGCVR performed the data analysis and wrote the first draft of the manuscript. MD advised and supervised the carrying out of the immunoassays. MSvdL contributed to the statistical analysis. GBS and AvdH made substantial changes to the manuscript. All authors read and approved the final manuscript.

Received: 17 November 2011 Accepted: 21 June 2012 Published: 21 June 2012

\section{References}

1. Arvin AM: Varicella-zoster virus. Clin Microbiol Rev 1996, 9:361-381.

2. Health Council of the Netherlands: The future of the National Immunisation Programme: towards a programme for all age groups. 2007. http://www. gezondheidsraad.nl/en/publications/future-national-immunisationprogramme-towards-programme-all-age-groups

3. de Melker HE, Berbers $G$, Hahne S, Rumke H, van den Hof S, de Wit A, Boot $\mathrm{H}$ : The epidemiology of varicella and herpes zoster in The Netherlands: implications for varicella zoster virus vaccination. Vaccine 2006, 24:3946-3952.

4. de Melker HE, Nagelkerde NJ, Conyn-van Spaendonck MA: Nonparticipation in a population-based seroprevalence study of vaccinepreventable diseases. Epidemiol Infect 2000, 124:255-262

5. Nardone A, de Ory F, Carton M, Cohen D, van Damme P, Davidkin I, Rota MC, de Melker H, Mossong J, Slacikova M, et al: The comparative seroepidemiology of varicella zoster virus in 11 countries in the European region. Vaccine 2007, 25:7866-7872.

6. Nichols RA, Averbeck KT, Poulsen AG, al Bassam MM, Cabral F, Aaby P, Breuer J: Household size is critical to varicella-zoster virus transmission in the tropics despite lower viral infectivity. Epidemics 2011, 3:12-18.

7. Rice PS: Ultra-violet radiation is responsible for the differences in global epidemiology of chickenpox and the evolution of varicella-zoster virus as man migrated out of Africa. Virol J 2011, 8:189.

8. Agyemang C, Ujcic-Voortman J, Uitenbroek D, Foets M, Droomers M: Prevalence and management of hypertension among Turkish, Moroccan and native Dutch ethnic groups in Amsterdam, the Netherlands: The Amsterdam Health Monitor Survey. J Hypertens 2006, 24:2169-2176.

9. Uitenbroek DG, Ujcic-Voortman JK, Janssen AP, Tichelman PJ, Verhoeff AP: Gezond zijn en geoznd leven in Amsterdam, the Amsterdam Health Monitor: 2006. http://www.os.amsterdam.nl/pdf/2006_gezondheidsmonitor_2004.pdf

10. Breuer J, Schmid DS, Gershon AA: Use and limitations of varicella-zoster virus-specific serological testing to evaluate breakthrough disease in vaccinees and to screen for susceptibility to varicella. J Infect Dis 2008, 197(Suppl 2):S147-S151.

11. Baaten GG, Sonder GJ, Dukers NH, Coutinho RA, Van den Hoek JA Population-based study on the seroprevalence of hepatitis $A, B$, and C virus infection in Amsterdam, 2004. J Med Virol 2007, 79:1802-1810.

12. Fassaert T, de Wit MA, Verhoeff AP, Tuinebreijer WC, Gorissen WH, Beekman AT, Dekker J: Uptake of health services for common mental disorders by first-generation Turkish and Moroccan migrants in the Netherlands. BMC Public Health 2009, 9:307.

13. Heininger U, Braun-Fahrlander C, Desgrandchamps D, Glaus J, Grize L, Wutzler P, Schaad UB: Seroprevalence of varicella-zoster virus immunoglobulin $\mathrm{G}$ antibodies in Swiss adolescents and risk factor analysis for seronegativity. Pediatr Infect Dis J 2001, 20:775-778.

14. Khoshnood B, Debruyne M, Lancon F, Emery C, Fagnani F, Durand I, Floret D: Seroprevalence of varicella in the French population. Pediatr Infect Dis J 2006, 25:41-44

15. Mossong J, Putz L, Schneider F: Seroprevalence and force of infection of varicella-zoster virus in Luxembourg. Epidemiol Infect 2004, 132:1121-1127.

16. Salleras $L$, Dominguez A, Vidal J, Plans $P$, Salleras M, Taberner J Seroepidemiology of varicella-zoster virus infection in Catalonia (Spain). Rationale for universal vaccination programmes. Vaccine 2000, 19:183-188.

17. Thiry N, Beutels P, Shkedy Z, Vranckx R, Vandermeulen C, Wielen MV Damme PV: The seroepidemiology of primary varicella-zoster virus infection in Flanders (Belgium). Eur J Pediatr 2002, 161:588-593.

18. Vyse AJ, Gay NJ, Hesketh LM, Morgan-Capner P, Miller E: Seroprevalence of antibody to varicella zoster virus in England and Wales in children and young adults. Epidemiol Infect 2004, 132:1129-1134.
19. Wutzler P, Farber I, Wagenpfeil S, Bisanz H, Tischer A: Seroprevalence of varicella-zoster virus in the German population. Vaccine 2001, 20:121-124.

20. Liyanage NP, Fernando S, Malavige GN, Mallikahewa R, Sivayogan S, Jiffry MT, Vitarana T: Seroprevalence of varicella zoster virus infections in Colombo district, Sri Lanka. Indian J Med Sci 2007, 61:128-134.

21. Mandal BK, Mukherjee PP, Murphy C, Mukherjee R, Naik T: Adult susceptibility to varicella in the tropics is a rural phenomenon due to the lack of previous exposure. J Infect Dis 1998, 178(Suppl 1):S52-S54

22. Knowles SJ, Grundy K, Cahill I, Cafferkey MT: Susceptibility to infectious rash illness in pregnant women from diverse geographical regions. Commun Dis Public Health 2004, 7:344-348.

23. Huisman J: An outbreak of varicella among a group of West Indians residing in the Netherlands. Ned Tijdschr Geneeskd 1966, 110:2099-2101.

24. Barnett ED, Christiansen D, Figueira M: Seroprevalence of measles, rubella, and varicella in refugees. Clin Infect Dis 2002, 35:403-408.

25. Gabutti G, Fedele A, Aprile V, Guido M, Lopalco P: Immigration flows and new epidemiological evidence in southern Italy. Vaccine 2003, 21:399-400.

26. Kjersem $\mathrm{H}$, Jepsen $\mathrm{S}$ : Varicella among immigrants from the tropics, a health problem. Scand J Soc Med 1990, 18:171-174.

27. Merrett $P$, Schwartzman K, Rivest $P$, Greenaway C: Strategies to prevent varicella among newly arrived adult immigrants and refugees: a costeffectiveness analysis. Clin Infect Dis 2007, 44:1040-1048.

28. Cohen DI, Davidovici BB, Smetana Z, Balicer RD, Klement E, Mendelson E, Green MS: Seroepidemiology of Varicella zoster in Israel prior to largescale use of varicella vaccines. Infection 2006, 34:208-213.

29. Heininger U, Seward JF: Varicella. Lancet 2006, 368:1365-1376.

30. Silhol R, Alvarez FP, Arena C, Amoros JP, Flahault A, Hanslik T, Boelle PY: Micro and macro population effects in disease transmission: the case of varicella. Epidemiol Infect 2010, 138:482-490.

31. van Lier A, van der Maas NA, Rodenburg GD, Sanders EA, de Melker HE: Hospitalization due to varicella in the Netherlands. BMC Infect Dis 2011, 11:85.

32. Brisson M, Edmunds WJ, Gay NJ, Law B, De SG: Modelling the impact of immunization on the epidemiology of varicella zoster virus. Epidemiol Infect 2000, 125:651-669.

33. Boot HJ, de Melker HE, Stolk EA, de Wit GA, Kimman TG: Assessing the introduction of universal varicella vaccination in the Netherlands. Vaccine 2006, 24:6288-6299.

34. Brisson M, Edmunds WJ, Gay NJ: Varicella vaccination: impact of vaccine efficacy on the epidemiology of VZV. J Med Virol 2003, 70(Suppl 1):S31-\$37.

35. Sengupta N, Booy R, Schmitt HJ, Peltola H, Van-Damme P, Schumacher RF, Campins M, Rodrigo C, Heikkinen T, Seward J, et al: Varicella vaccination in Europe: are we ready for a universal childhood programme? Eur J Pediatr 2008, 167:47-55.

36. Boelle PY, Hanslik T: Varicella in non-immune persons: incidence, hospitalization and mortality rates. Epidemiol Infect 2002, 129:599-606

37. Noorda J, Hoebe CJ: Fatal outbreak of chickenpox (varicella-zoster virus infection) among institutionalised adults with learning difficulties. Commun Dis Public Health 2004, 7:164-168.

38. Leikin E, Figueroa R, Bertkau A, Lysikiewicz A, Visintainer P, Tejani N: Seronegativity to varicella-zoster virus in a tertiary care obstetric population. Obstet Gynecol 1997, 90:511-513.

doi:10.1186/1471-2334-12-140

Cite this article as: Rijckevorsel et al:: Seroprevalence of varicella-zoster virus and predictors for seronegativity in the Amsterdam adult population. BMC Infectious Diseases 2012 12:140. 